Article

\title{
Capacity of Aromatic Compound Degradation by Bacteria from Amazon Dark Earth
}

\author{
Fernanda Mancini Nakamura ${ }^{1, *}$, Mariana Gomes Germano ${ }^{2}$ and Siu Mui Tsai ${ }^{1}$ \\ 1 Universidade de São Paulo (USP), Centro de Energia Nuclear na Agricultura (CENA), \\ Laboratório de Biologia Celular e Molecular, Avenida Centenário, n 303, Piracicaba, \\ SP CEP 13400-970, Brazil; E-Mail: tsai@cena.usp.br \\ 2 Embrapa Soja, Rodovia Carlos João Strass, Distrito de Warta, Caixa Postal 231, Londrina, \\ PR CEP 86001-970, Brazil; E-Mail: mgermano@cnpso.embrapa.br \\ * Author to whom correspondence should be addressed; E-Mail: fnakamura@cena.usp.br; \\ Tel.: +55-19-3429-4643.
}

Received: 10 March 2014; in revised form: 3 June 2014 / Accepted: 4 June 2014 /

Published: 16 June 2014

\begin{abstract}
Amazon dark earth (ADE) is known for its high organic matter content, biochar concentration and microbial diversity. The biochar amount suggests the existence of microorganisms capable of degrading aromatic hydrocarbons (AHs). In an effort to investigate the influence of bacteria on the resilience and fertility of these soils, we enriched five ADE soils with naphthalene and phenanthrene, and biodegradation assays with phenanthrene and diesel oil were carried out, as well. After DNA extraction, amplification and sequencing of the 16S rRNA bacterial gene, we identified 148 isolates as the Proteobacteria, Firmicutes and Actinobacteria phyla comprising genera closely related to AHs biodegradation. We obtained 128 isolates that degrade diesel oil and 115 isolates that degrade phenanthrene. Some isolates were successful in degrading both substrates within $2 \mathrm{~h}$. In conclusion, the obtained isolates from ADE have degrading aromatic compound activity, and perhaps, the biochar content has a high influence on this.
\end{abstract}

Keywords: Terra Preta de Índio; microbial ecology; genetic diversity; phenanthrene; diesel oil; biodegradation assay 


\section{Introduction}

Amazon dark earth (ADE) has a stable micro-ecosystem that sustains itself [1] (There is a great presence of vegetable, animal, ceramic, biochar and ash residues and existing high aromatic hydrocarbon concentrations. Biochar, as the black material of carbon associated with agriculture is named, is the most recalcitrant portion of organic matter from partial lignin burning, hemicellulose and cellulose and is rich in polyaromatic hydrocarbon-condense units [2]. Because of its porosity, biochar fragments can retain water, can be protective structures [3] and can be carbon sources for microorganisms [4]. All of these characteristics indicate that the biological activity strongly influences the nutrient cycles of this environment.

Aromatic hydrocarbons (AHs) are a class of hydrophobic organic compounds made of casted aromatic rings with linear and angular molecular arrangements, and they are found in the environment due to the processing of wood, char, creosote, petroleum mud, asphalt and pesticides [5]. These substances can be bioactive, but persist in ecosystems for years, due to the low solubility in water and to the adsorption on solid particles [6].

Biodegradation by microorganisms is an adaptation mechanism for the survival of the microbial community, since gene transference and mutation are essential for the metabolism of different carbon compounds [7,8]. Thus, much research has focused on the biological degradation of AHs through metabolism and co-metabolism [9]. Sayler et al. [10] demonstrated the positive correlation between the AH mineralization rates on oil-contaminated sediments and bacterial colony number with its own plasmids with genes that code for the degradation of AH enzymes.

$\mathrm{AH}$ degradation by bacteria is due to genes from plasmids or nuclear DNA and sometimes both [11]. These genes jointly act to produce degrader phenotypes for a determined substrate and allow its utilization as a carbon and energy source [12]. The degradation process involves enzyme machinery: dehalogenases, dehydrogenases and hydrolases system [13].

Amongst the several microorganisms that are found on ADE, the most abundant bacteria are from the phyla, Firmicutes, Proteobacteria, Verrucomicrobia, Acidobacteria and Actinobacteria [14,15]. Some members have an infinite number of beneficial characteristics for ecology and the economy, being biodegraders, as well. Thus, detailed studies with these genera have become necessary to discover new strategies for biotechnological, agricultural and pharmaceutical uses.

Studies by isolation in association with molecular analyses comprise the best way to analyze the physiology and phylogeny of an organism. Furthermore, bioassays are crucial to observing the activity efficiency by means of controlled conditions with laboratory evaluations [16].

\section{Experimental Section}

The study areas were from Central Amazon with distinct land uses and vegetal covering. The Balbina area (BAL) $\left(01^{\circ} 30^{\prime} 26,4^{\prime \prime}\right.$ S-6005'34" W), located at Presidente Fiqueiredo City (Amazonas State, AM), has medium secondary rainforest (capoeira ) coverage and is considered a model for the original ADE, since it has not been cultivated or deforested for more than 20 years. The area within the Caldeirão Experimental Station (CAL) (Embrapa Centro de Pesquisa Agroflorestal da Amazônia Ocidental, CPAA) $\left(03^{\circ} 15^{\prime} 11^{\prime \prime} \mathrm{S}-60^{\circ} 13^{\prime} 43^{\prime \prime} \mathrm{W}\right)$ is located at Iranduba City (AM), also under capoeira. 
The Barro Branco area (BB) $\left(03^{\circ} 18^{\prime} 24.76^{\prime \prime} \mathrm{S}-60^{\circ} 32^{\prime} 05.10^{\prime \prime} \mathrm{W}\right)$ is located next to Iranduba City (AM), under Citrus culture. The Costa do Açutuba (ACU) $\left(03^{\circ} 05^{\prime} 53.92^{\prime \prime S}-60^{\circ} 21^{\prime} 19.90^{\prime \prime W}\right)$ and Hatahara (HATA) (03 $\left.16^{\prime} 28.45^{\prime \prime} \mathrm{S}-60^{\circ} 12^{\prime} 17.14^{\prime \prime} \mathrm{W}\right)$ areas are ADE sites that have been extensively analyzed by pedo-archaeological expeditions, being utilized for intentional anthropogenic activities based on intensive management on bare places [17].

\subsection{Sampling}

Samples were collected from depths of $0-10 \mathrm{~cm}$ at a georeferenced central point and two other points $1.5 \mathrm{~m}$ away, and also, 3 subsamples $30 \mathrm{~cm}$ from each other were collected from each point. The sampling was performed in plastic tubes of $5 \times 10 \mathrm{~cm}$ and stored in thermal boxes with dry ice, then sent to the Laboratório de Biologia Celular e Molecular (BCM) of the Center of Nuclear Energy in Agriculture, the University of São Paulo, Piracicaba-São Paulo State, Brazil. One part was stored below $4{ }^{\circ} \mathrm{C}$ for microbial and chemical analyses, while another part was stored at $-20{ }^{\circ} \mathrm{C}$ for molecular analyses.

\subsection{Enrichment Assay}

One gram of soil in triplicate was added to mineral medium Bushnell Haas (Difco, Detroit, MI, USA) with naphthalene 99\% and phenanthrene 98\% (Sigma Aldrich, St. Louis, MO, USA) (diluted in ethanol 100\%) at concentrations of $0.05 \%(w / v)$ [18] as carbon and energy sources The negative control was composed by mineral medium and AHs. The positive controls were standards from the Leibniz Institute DSMZ - German Collection of Microorganisms and Cell Cultures, Braunschweig, Germany (DSMZ) culture collection within the mineral medium (Table 1). The mesocosms were incubated at $30{ }^{\circ} \mathrm{C}$ with $300 \mathrm{rpm}$ shaking for 15 days. A subculture was carried out under the same conditions. Finally, the cultures were grown on solid medium previously treated with $200 \mu \mathrm{L}$ of alcoholic solution of AHs at a concentration of $50 \mathrm{ppm}$ on its surface for the attainment of bacterial colonies from serial dilutions $\left(10^{3}\right.$ to $\left.10^{6}\right)$. The satisfactory quantity was between 30 and 300 colonies. Later, the purified colonies were grown in liquid tryptic soy medium (Difco, Detroit, MI, USA), and the genomic DNA extraction was carried out as described by Doyle [19], followed by storage in $40 \%$ glycerol in an ultra-freezer.

Table 1. Positive standards utilized on the enrichment assay. AH, aromatic hydrocarbon.

\begin{tabular}{cc}
\hline DSMZ Standard & AH Metabolism \\
\hline P. putida (DSM 6899) & toluene dioxygenase \\
P. putida (DSM 291) & \\
P. fluorescens (DSM 8369) & naphthalene dioxygenase \\
P. abietaniphila (DSM 6506) & \\
\hline
\end{tabular}

\subsection{Isolates Identification}

\subsubsection{S rRNA Gene of Bacteria Amplification}

To identify the isolates, a conventional PCR was performed with external primers fD1 (5'-AGAGT TTGATCCTGGCTCAG-3') and rD1 (5'-AAGGAGGTGATCCAGCC-3') [20]. The conditions were: 5 
pmol of primers, $200 \mu \mathrm{M}$ of each dNTP (Life Technologies of Brazil, São Paulo, Brazil), 1 x Taq buffer (Life Technologies of Brazil, São Paulo, Brazil), $1.5 \mathrm{mM} \mathrm{MgCl}$ (Life Technologies of Brazil, São Paulo, Brazil), 2 U Platinum Taq DNA polymerase (Life Technologies of Brazil, São Paulo, Brazil) and $10 \mathrm{ng}$ of DNA at a final volume of $25 \mu \mathrm{L}$. The reaction was initiated with 3 min of denaturation at $94{ }^{\circ} \mathrm{C}$, followed by 30 cycles with denaturation at $94{ }^{\circ} \mathrm{C}$ for $1 \mathrm{~min}$, annealing at $55{ }^{\circ} \mathrm{C}$ for $30 \mathrm{~s}$, extension at $72{ }^{\circ} \mathrm{C}$ for $30 \mathrm{~s}$ and a final extension of $72{ }^{\circ} \mathrm{C}$ for $10 \mathrm{~min}$.

\subsubsection{Sequencing Reaction}

To generate information about the main degrading bacterial genera from ADE, 16S rRNA gene sequencing was done. The precipitation of PCR products was achieved by the addition of isopropanol, followed by incubation, centrifugation and resuspension in $30 \mu \mathrm{L}$ of autoclaved ultrapure water. The reaction was performed using the DYEnamic ET Terminator Cycle Sequencing Kit (GE Healthcare, São Paulo, Brazil) in a final volume of $10 \mu \mathrm{L}$, with one reaction for each primer: $200 \mathrm{ng}$ of PCR product; 5 pmol of primer; $0.5 \mathrm{X}$ of buffer; and $2.0 \mu \mathrm{L}$ of DYEnamic ET Terminator Cycle. The conditions were: $2 \mathrm{~min}$ at $96{ }^{\circ} \mathrm{C}, 30$ cycles at $95{ }^{\circ} \mathrm{C}$ for $20 \mathrm{~s}$, annealing at $55^{\circ} \mathrm{C}$ for $15 \mathrm{~s}$ and extension at $60{ }^{\circ} \mathrm{C}$ for $1 \mathrm{~min}$. Afterwards, precipitation was carried out to eliminate the dNTPs not used with $1 \mu \mathrm{L}$ of sodium acetate/EDTA, $40 \mu \mathrm{L}$ of ethanol $95 \%$ and centrifugation at $12,000 \mathrm{rpm}$ for $15 \mathrm{~min}$; the supernatant was discarded, and $500 \mu \mathrm{L}$ of ethanol $70 \%$ was added, followed by centrifugation for 5 min, discarding of the supernatant, drying in a DNA concentrator for $5 \mathrm{~min}$ at $40{ }^{\circ} \mathrm{C}$ and resuspension in $10 \mu \mathrm{L}$ of formamide (Life Technologies of Brazil, São Paulo, Brazil). The microplate was placed in the thermocycler to denature the DNA at $96{ }^{\circ} \mathrm{C}$ for $5 \mathrm{~min}$ and immediately placed on ice for $2 \mathrm{~min}$. The reading of the marked bases were done by the automatic sequencer, ABI Prism 3130 Genetic Analyzer (Life Technologies, Carlsbad, NM, USA), which utilizes capillary electrophoresis for the separation and detection of amplified fragments of $\leq 1500 \mathrm{bp}$ in length [21].

\subsubsection{Phylogenetic Analysis}

Reads were edited by the removal of low quality bases ( $<20$ Phred quality) and the formation of contigs through the Phred/Phrap/Consed software [22-24]. The partial contigs of the 16S rRNA gene were analyzed on the Ribosomal Database Project (RDP) Classifier server [25]for the isolates' genera and on the EzTaxon server [26] for the isolates' species to corroborate the data. The nucleotide sequences described in this study have been submitted to the GenBank database of the National Center for Biological Information under the accession numbers, KJ524106-KJ524135 and KJ524136-KJ524271.

\subsection{Biodegradation Assays}

\subsubsection{Cell Density}

To study the equal efficiency of biodegradation by isolates, there is a need to use the same and known amount of cells on the inoculum. In this case, $10^{8}-10^{9}$ cells per $\mathrm{mL}$ (cells $/ \mathrm{mL}$ ), measured by cell counting under microscope (Bel Photonics, Osasco, Brazil) with a Neubauer Chamber (Boeco, Hamburg, Germany) and spectrophotometry with Nanodrop 2000c (Thermo Scientific, West Palm Beach, FL, USA) at a wavelength of $600 \mathrm{~nm}$. Due to different morphology, size and color, the isolates 
were classified under these characteristics, and 20 types were obtained. One isolate of each type was utilized as a standard for the optical density with dilutions and calculations as described by Lelliott and Stead [27], a graphic relating cell number and OD for each of the 20 types of models being constructed. Then, the inoculants were prepared in nutrient broth medium (Oxoid, Basingstoke, UK) at $170 \mathrm{rpm}$ for $12 \mathrm{~h}$ at $32{ }^{\circ} \mathrm{C}$. Every evaluation of each OD of isolates was plotted to its correspondent graphic type beyond each graphic formula. The final volume of inoculants varied between 4 to $50 \mu \mathrm{L}$.

\subsubsection{The Assays}

To evaluate the isolates efficiency of AH biodegradation, the assay was performed as described by Hanson et al. [28] with the 148 isolates in triplicate in polystyrene 96-well microplates, together with positive and negative controls, also in triplicate. This assay is based on the redox indicator 2,6-diclorofenol-indofenol (DCPIP) principle of discoloration when electrons are released in the environment by the bacterial cells when they use the substrates. The molecular conformation of the indicator, then, changes and reflects the light differently, turning its coloration from blue (oxidized form) to colorless (reduced form). The redox indicator used was 2,6-diclorofenol-indofenol (DCPIP) (Sigma Aldrich, St Louis, MO, USA) (diluted in ultrapure water and filtered through a $0.22-\mu \mathrm{m}$ membrane) at $0.2 \%$ in the final volume. The substrates used were phenanthrene (diluted in acetone and filtered through a $0.22-\mu \mathrm{m}$ membrane), as a strictly controlled assay, and commercial diesel oil (Shell, Piracicaba, Brazil) (filtered through a $0.22-\mu \mathrm{m}$ membrane), as a possible practical use. The positive control used was DSM11192 Gordonia sp., as described in Table 2. The negative controls consisted only of mineral medium, substrates, the redox indicator and Nutriente Broth (NB) medium without inoculants.

Table 2. Positive standard utilized in the bioassays.

\begin{tabular}{ccc}
\hline No. DSMZ & Microorganism & AH metabolism \\
\hline DSM 11192 & Gordonia sp. & n-alkane, naphthalene, toluene, m-xylene, p-xylene \\
\hline
\end{tabular}

A pretest was done with the positive control with phenanthrene concentrations of $0.05 \%, 0.1 \%, 0.2 \%$, $0.4 \%, 0.8 \%$ and $1 \%$ in the final volume, and with diesel oil concentrations of $0.5 \%, 1 \%, 2 \%, 4 \% 8 \%$ and $16 \%$ in the final volume. The best substrates concentrations, or the minimum inhibition, for the microorganism were $0.05 \%$ of phenanthrene and $8 \%$ of diesel oil, and the degradation activity was observed to begin by $8 \mathrm{~h}$ for diesel oil and $24 \mathrm{~h}$ for phenanthrene by DSM11192. The concentrations of $0.1 \%$ and $0.2 \%$ of phenanthrene inhibited DSM11192; although, the maximum concentration of diesel tolerated was $16 \%$.

Finally, after the volume of cells, substrate and redox indicator, a mineral medium Bushnell Haas (BH) (Difco, Detroit, MI, USA) was added to complete the $200 \mu \mathrm{L}$. The microplates were maintained in dark at room temperature $\left(18{ }^{\circ} \mathrm{C}\right)$ and orbital shaking of $170 \mathrm{rpm}$, and measurements were made at $2 \mathrm{~h}$, $4 \mathrm{~h}, 8 \mathrm{~h}, 16 \mathrm{~h}, 24 \mathrm{~h}$ and $40 \mathrm{~h}$ on the spectrophotometer, Multiskan FC, (Thermo Scientific, West palm Beach, FL, USA), with shake mode before measurement at $620 \mathrm{~nm}$, which captures the blue DCPIP as a chromosphere. Photos were also taken. As the absorbances are in inverted relation to the degradation rate, we normalized the data, subtracting from 1, and the rates were obtained based on the negative control absorbance. Negative rates indicate the degradation of substrates and refer to low chromosphere 
absorbance for each time of measurement, indicating degradation activity by isolates when enzymes act on aromatic substrates molecules, releasing oxygen atoms to the medium and leading to a change of DCPIP color.

\section{Results and Discussion}

From the enrichment assay with the five ADE soils, we could isolate, sequence and study the biodegradation capacity of a total of 148 bacteria: 48 from Costa do Açutuba, 71 from Hatahara, 14 from Caldeirão, nine from Barro Branco and from Balbina. The 16S rRNA gene sequences with a length $\geq 400 \mathrm{bp}$ were identified from the RDP database, and all names are in the Supplementary Material. It was possible to obtain bacterial representatives of the phyla, Proteobacteria, Actinobacteria and Firmicutes.

From the identification at EzTaxon-e, it was possible to observe that the majority of the isolated $16 \mathrm{~S}$ rRNA sequences were similar to those in the database from contaminated areas, as well as the isolates from degradation bioassays with aromatic hydrocarbons.

The isolates' identification corroborates Navarrete et al. [14] and Germano et al. [15], who studied the bacterial community of ADE by strict molecular analysis and found the following bacterial phyla: Firmicutes, Proteobacteria, Verrucomicrobia, Acidobacteria, Gemmatimonadetes, Actinobacteria and Nitrospira.We had $78 \%$ of positive isolates for the degradation of phenanthrene and $86 \%$ of positive isolates for the degradation of diesel oil, but there were degradation capacity variations, which can be seen in Figures 1 and 2, for phenanthrene and diesel oil, respectively. In the Supplementary Material we provide the full visualization of all isolates for each substrate degradation. However, after observing small absorbance, high percentages since $24 \mathrm{~h}$ or less were observed for the $\mathrm{pH}$ change as a result of cell growth. Therefore, this changed the DCPIP light reflection from colorless to light purple, now being another chromosphere captured by the spectrophotometer, and the amount of cells was an additional material that was captured by $620 \mathrm{~nm}$. However, this affected our results, once we had already registered the previous absorbance.

It was possible to observe a clear decay on the absorbance data beginning at $2 \mathrm{~h}$ for $24.35 \%$ of the positive isolates for phenanthrene degradation and $27 \%$ of the positive isolates for diesel degradation. After $4 \mathrm{~h}, 0.87 \%$ degraded phenanthrene and $6 \%$ of the positive isolates degraded diesel. After $8 \mathrm{~h}$, $5.22 \%$ of the positive isolates degraded phenanthrene and $30 \%$ of the positive isolates degraded diesel oil. After 16 h, 45.22\% degraded phenanthrene and 29\% of the positive isolates degraded diesel oil. After $24 \mathrm{~h}, 19 \%$ of the positive isolates degraded phenanthrene and $9 \%$ of the positive isolates degraded diesel oil. Finally, after $40 \mathrm{~h}, 5 \%$ of the positive isolates for phenanthrene degradation degraded phenanthrene and $5 \%$ of the positive isolates for diesel oil degraded diesel. For the positive control, similar degradation rates to the pretest were observed, and degradation began at $8 \mathrm{~h}$ for diesel and $24 \mathrm{~h}$ for phenanthrene. 
Figure 1. Visualization of the best isolates rates for the degradation of $0.05 \%$ of phenanthrene after (a) $2 \mathrm{~h}$; (b) $4 \mathrm{~h}$; (c) $8 \mathrm{~h}$; (d) $16 \mathrm{~h}$; (e) $24 \mathrm{~h}$; and (f) $40 \mathrm{~h}$; measured at $620 \mathrm{~nm}$. Negative data indicate degradation. The positive control is at the top of the figure, and the genus of each isolate is shown.

(a) Phenanthrene degradation activity after $2 \mathrm{~h}$

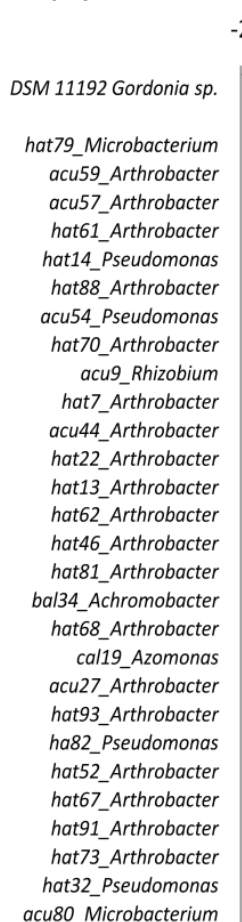

(1)

(b) Phrenanthrene deradation activity after $4 \mathrm{~h}$ 1 (d) Phenanthrene degradation activity after $\mathbf{1 6} \mathrm{h}$
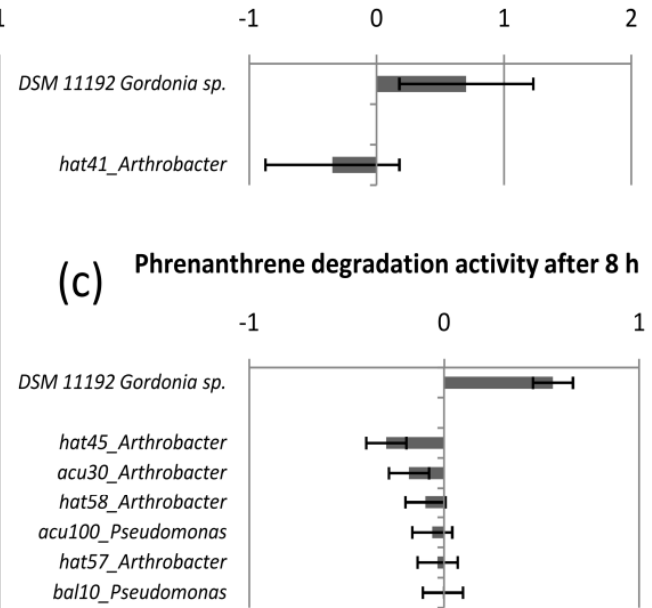

(f) Phenanthrene degradation activity after $40 \mathrm{~h}$

DSM 11192_Gordonia sp.
hat84_Pseudomonas
acu1_Pseudomonas
ccu40_Stenothrophomonas
acu17_Citricoccus
acu34_Pseudomonas
hat71_Pseudomonas

(e) Phenanthrene degradation activity after $24 \mathrm{~h}$

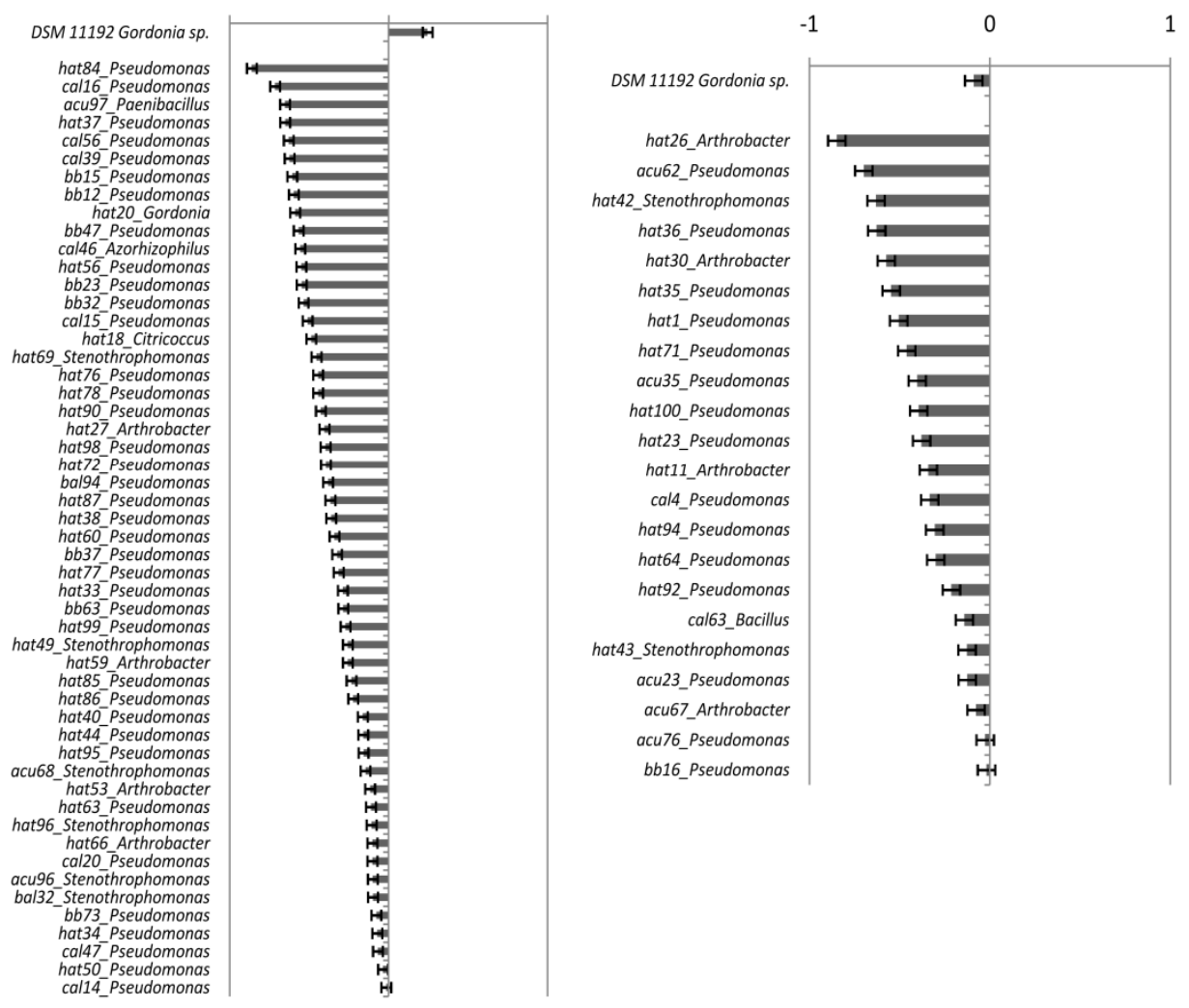


Figure 2. Visualization of the best isolate rates for the degradation of $8 \%$ of diesel after (a) $2 \mathrm{~h}$; (b) $4 \mathrm{~h}$; (c) $8 \mathrm{~h}$; (d) $16 \mathrm{~h}$; (e) $24 \mathrm{~h}$; and (f) $40 \mathrm{~h}$; measured at A620 nm. Negative data indicate degradation. The positive control is at the top of the figure, and the genus of each isolate is shown.

(a) Diesel oil degradation activity after $2 \mathrm{~h}$

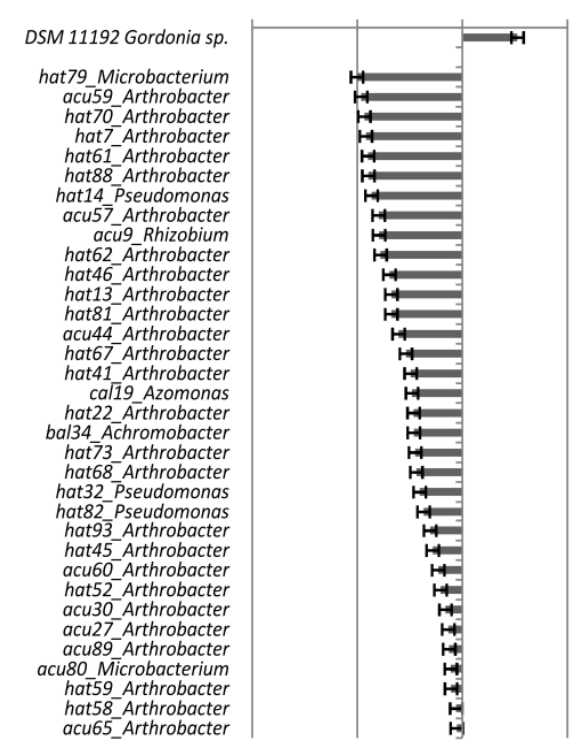

(b) Diesel oil degradation activity after $4 \mathrm{~h}$

DSM 11192 Gordonia sp.
hat98_Pseudomonas
hat57_Arthrobacter
acu96Stenothrophomonas
hat91_Arthrobacter
hat66_Arthrobacter
hat18_Citricoccus
acu98_Peudomonas
acu35_Pseudomonas

(C) Diesel oil degradation activity after $8 \mathrm{~h}$

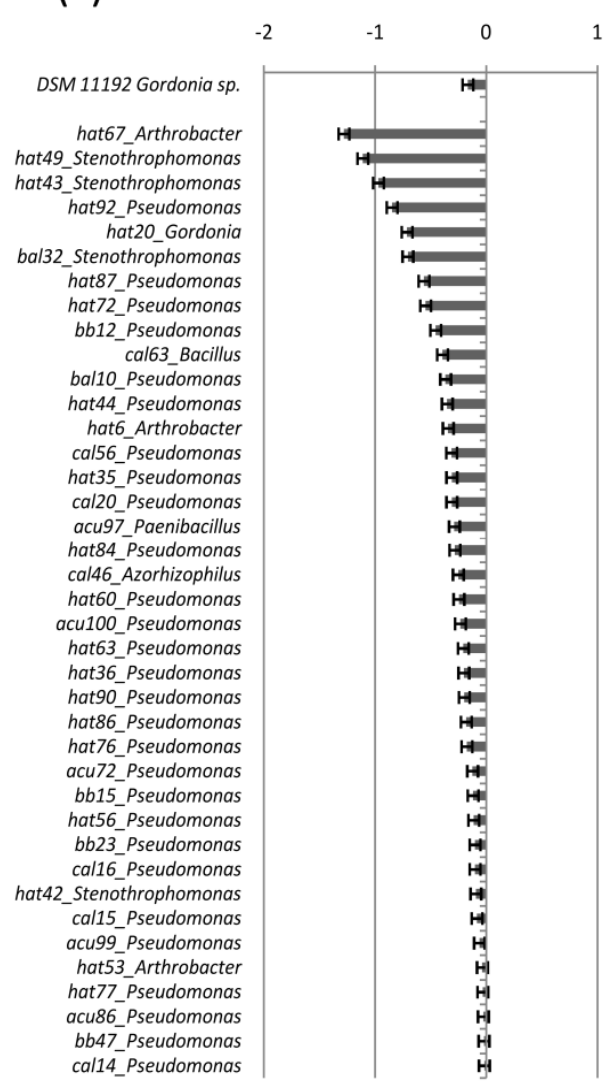

(d) Diesel oil degradation activity after $16 \mathrm{~h}$

DSM 11192 Gordonia Sp.

cal47_Pseudomona Cal27_Pseudomonas bb16-Pseudomonas hat38_Pseudomonas
bal94_Pseudomonas bali_peudomonas bb32_Pseudomonas hat11_Arthrobacter hat26_Arthrobacter cal6_Pseudomonas cal39_Pseudomonas acu1_Pseudomonas hat37_pseudomonas acu87_Pseudomonas cal4 Pseudomonas hat30 Arthrobacter hat33 Pseudomonas acu67_Arthrobacter hat100_Pseudomonas hat34_Pseudomonas hat1_Pseudomonas hat31_Arthrobacter hat85_Pseudomonas acu23 Pseudomonas hat64 Pseudomonas acu70_Pseudomonas acu68_Stenothrophomonas acu76_Pseudomonas

acu46_Stenothrophomonas hat95_Pseudomonas hat50-Pseudomonas hat 40 Pseudomonas hat99 Pseudomonas

(1)

(e) Diesel oil degradation activity after $24 \mathrm{~h}$

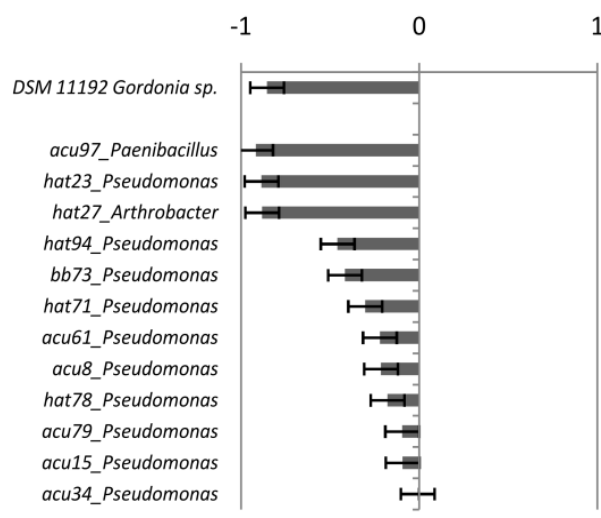

(f) Diesel oil degradation activity after $40 \mathrm{~h}$

$\left.\begin{array}{rl}\text { DSM } 11192 \text { Gordonia sp. } \\ \text { acu40_Stenothrophomonas } \\ \text { hat42_Stenothrophomonas } \\ \text { hat96_Stenothrophomonas } \\ \text { acu90_Pseudomonas } \\ \text { acu15_Pseudomonas } \\ \text { acu62_Pseudomonas }\end{array}\right)$


We could observe that many isolates developed a faster degradation activity of both substrates than the positive control. Furthermore, 24 isolates degraded both substrates within $2 \mathrm{~h}$ from the experiment start, and they can be seen in (a) from Figures 1 and 2 near the positive control.

Achromobacter bal 34 represents $4.16 \%$ of the best isolates for both substrates; Azomonas cal 19 represents 4.16\%; Rhizobium acu9 represents 4.16\%; Pseudomonas hat14 and hat32 represent 8.33\%; and Arthrobacter acu27, acu44, acu57, acu59, hat13, hat46, hat52, hat61, hat62, hat67, hat68, hat7, hat 81 , hat70, hat 88 and hat93 dominate, representing $62.5 \%$ of the best isolates for both substrates.

In Figures 3 and 4, we show the degradative capacity for phenanthrene and diesel oil, respectively, based on the isolates' genus.

Pseudomonas was the dominant genus in all of the ADE soils studied. They are highly adapted and distributed in all environments [29] and strongly related to the biodegradation of hydrocarbons [30]. Achromobacter, Azomonas and Stenotrophomonas also are related with aromatic hydrocarbons of diverse complexities [30-33] and were identified within the best degradative isolates for diesel oil. Isolates of Achromobacter, Azomonas and Rhizobium were found to degrade both substrates used in our bioassays. Furthermore, our isolate of Azorhizophilus degraded both phenanthrene and diesel oil. This genus has only two species, which have been documented as nitrogen-fixing bacteria [34], but interestingly, they have not been widely associated with AHs until now.

The second most dominant active group was represented by the Actinobacteria phylum, the organisms of which have versatile metabolism and are able to use diverse substrates, such as carbon, and energy sources. Most genera have great industrial interest, such as Arthrobacter, Rhodococcus and Gordonia, which are associated with saturated aliphatic and aromatic hydrocarbons [35-37], in addition to Citricoccus [38] and Microbacterium. Methylobacterium is methane utilizing and degrades explosive compounds in association with plants [39]. Our bioassays strongly evidenced the degradative activity of Arthrobacter, Microbacterium and Gordonia isolates, found within the best degradative isolates for both substrates.

Bacillus and Paenibacillus are from the Firmicutes phylum, have also been found between the isolates from the enrichment assay and were active in the biodegradation assay, being described as aromatic hydrocarbon-degrading bacteria [30,31,40].

The disparity of the degradation of phenanthrene and diesel oil by isolates is due to phenanthrene being a pure substance, unlike diesel oil, which is a complex mixture of hydrocarbons, such as alkanes, cycloalkanes, polyaromatic hydrocarbons and sulfur [41]. Therefore, diesel oil provides a diverse carbon source, being more utilized by diverse degradation genes, differently from phenanthrene, with only certain genes, such as the $p n h A$ genes, that can produce the phenanthrene dioxygenases to degrade the substrate.

Thereby, our bioassay results show that the bacterial populations of the ADE are likely to be activated for the degradation of AHs as a survival characteristic.

The existence of this bacterial population, which consumes aromatic hydrocarbons in ADE, may be due to a great biochar content in ADE. Therefore, the existence of high amounts of biochar is perhaps a selective factor for the bacterial community, and horizontal gene transfer can be a cause for the existence of such a capacity in ADE bacteria. 
Figure 3. Visualization of the isolates based on their identification of the genus within phyla for the degradation of $0.05 \%$ of phenanthrene after (a) $2 \mathrm{~h}$; (b) $4 \mathrm{~h}$; (c) $8 \mathrm{~h}$; (d) $16 \mathrm{~h}$; (e) $24 \mathrm{~h}$; and (f) $40 \mathrm{~h}$; measured at $620 \mathrm{~nm}$. Negative data indicate degradation. The positive control is at the top of the figure, and the genus of each isolate is shown. Each colored bar indicates the time of degradation for a determined degradation rate.

Phenanthrene degradation by Actinobacteria isolates

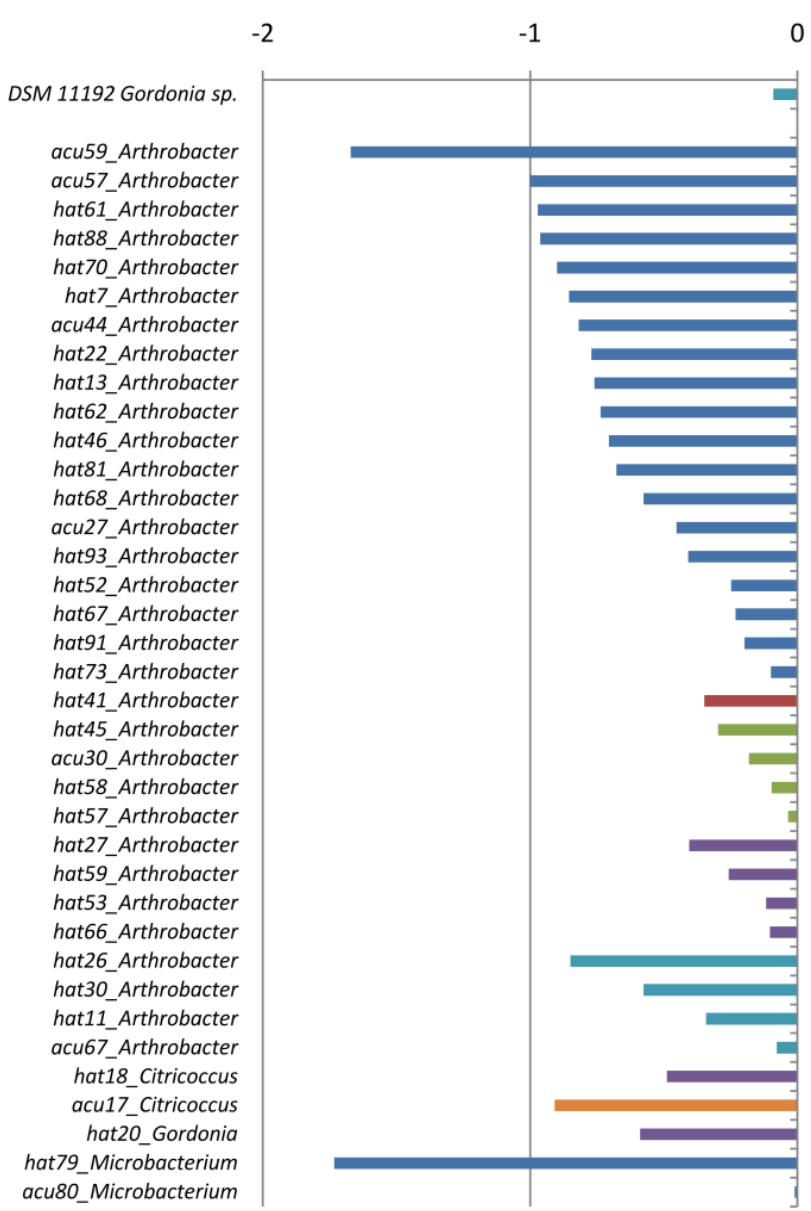

Phenanthrene degradation by Firmicutes isolates

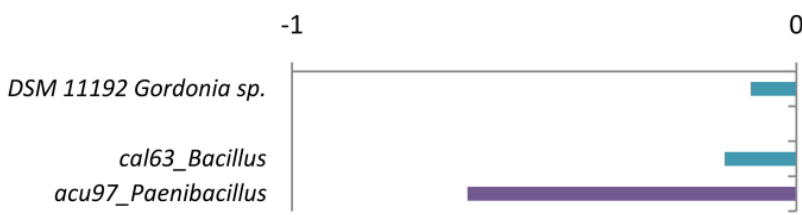

$-1$

0

DSM 11192 Gordonia sp.

bal34_Achromobacter cal19_Azomonas hat14 Pseudomonas acu54_Pseudomonas ha82 Pseudomonas hat32_Pseudomonas acu100_Pseudomonas bal10_Pseudomonas hat84_Pseudomonas cal16_Pseudomonas hat37 Pseudomonas cal56 Pseudomonas cal39_Pseudomonas bb15_Pseudomonas bb12_Pseudomonas bb47_Pseudomonas hat56_Pseudomonas bb23 Pseudomonas bb32_Pseudomonas cal15_Pseudomonos hat76_Pseudomonas hat78_Pseudomonas hat90_Pseudomonas hat98_Pseudomonas hat72 Pseudomonas bal94_Pseudomonas hat87_Pseudomonos hat38_Pseudomonas hat60_Pseudomonas bb37_Pseudomonas hat77_Pseudomonas hat33 Pseudomonas bb63_Pseudomonas hat99_Pseudomonos hat85_Pseudomona hat86_Pseudomona hat40_Pseudomonas hat44_Pseudomonas hat95 Pseudomonas hat63_Pseudomonas cal20_Pseudomonas bb73_Pseudomonas hat34_Pseudomona cal47_Pseudomonas hat50_Pseudomonas cal14 Pseudomonas acu62_Pseudomonas hat36_Pseudomona hat35_Pseudomonas hat1_Pseudomonas hat71_Pseudomonas acu35_Pseudomonas hat100 Pseudomonas hat23 Pseudomonas cal4_Pseudomonas hat94_Pseudomonas hat64_Pseudomonas hat92_Pseudomonas acu23_Pseudomonas acu 76 Pseudomonas bb16_Pseudomonas hat84_Pseudomonas acu1_Pseudomonas acu34_Pseudomonas hat71_Pseudomonas acu9_Rhizobium hat69 Stenothrophomonas hat49_Stenothrophomonas acu68_Stenothrophomonas hat96_Stenothrophomonas acu96_Stenothrophomonas bal32_Stenothrophomonas hat42 Stenothrophomonas hat43 Stenothrophomonas acu40 Stenothrophomonas

0

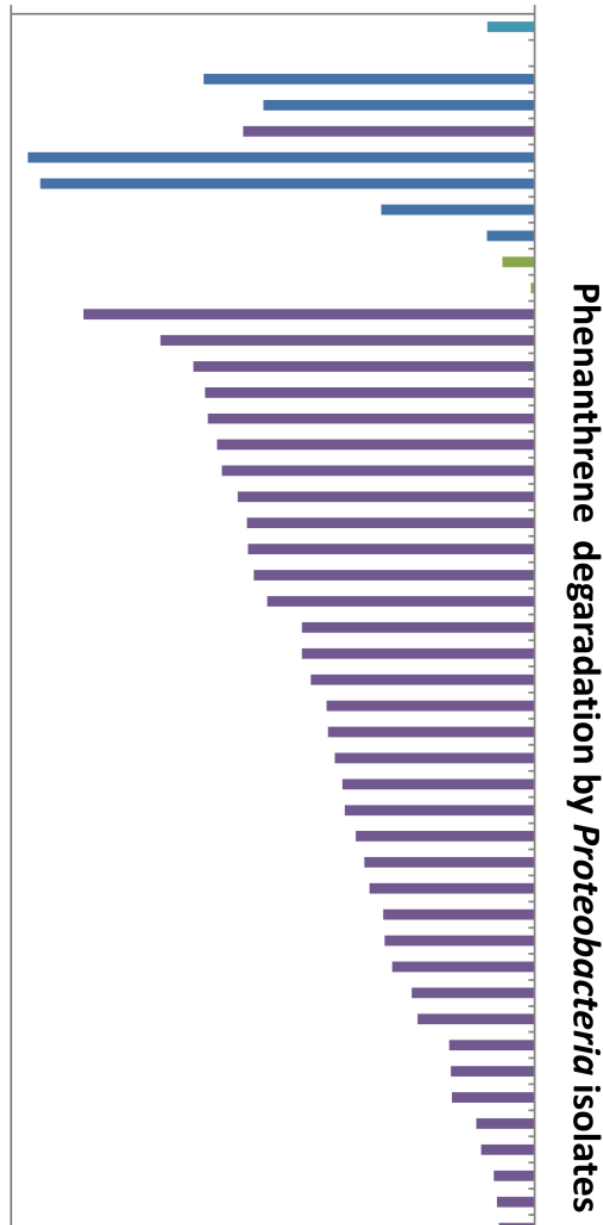


Figure 4. Visualization of the isolates based on their identification of the genus within the phyla for the degradation of $8 \%$ of diesel after $2 \mathrm{~h}, 4 \mathrm{~h}, 8 \mathrm{~h}, 16 \mathrm{~h}, 24 \mathrm{~h}$ and $40 \mathrm{~h}$ measured at $620 \mathrm{~nm}$. Negative data indicate degradation. The positive control is at the top of the figure, and the genus of each isolate is shown. Each colored bar indicates the time of degradation for a determined degradation rate.

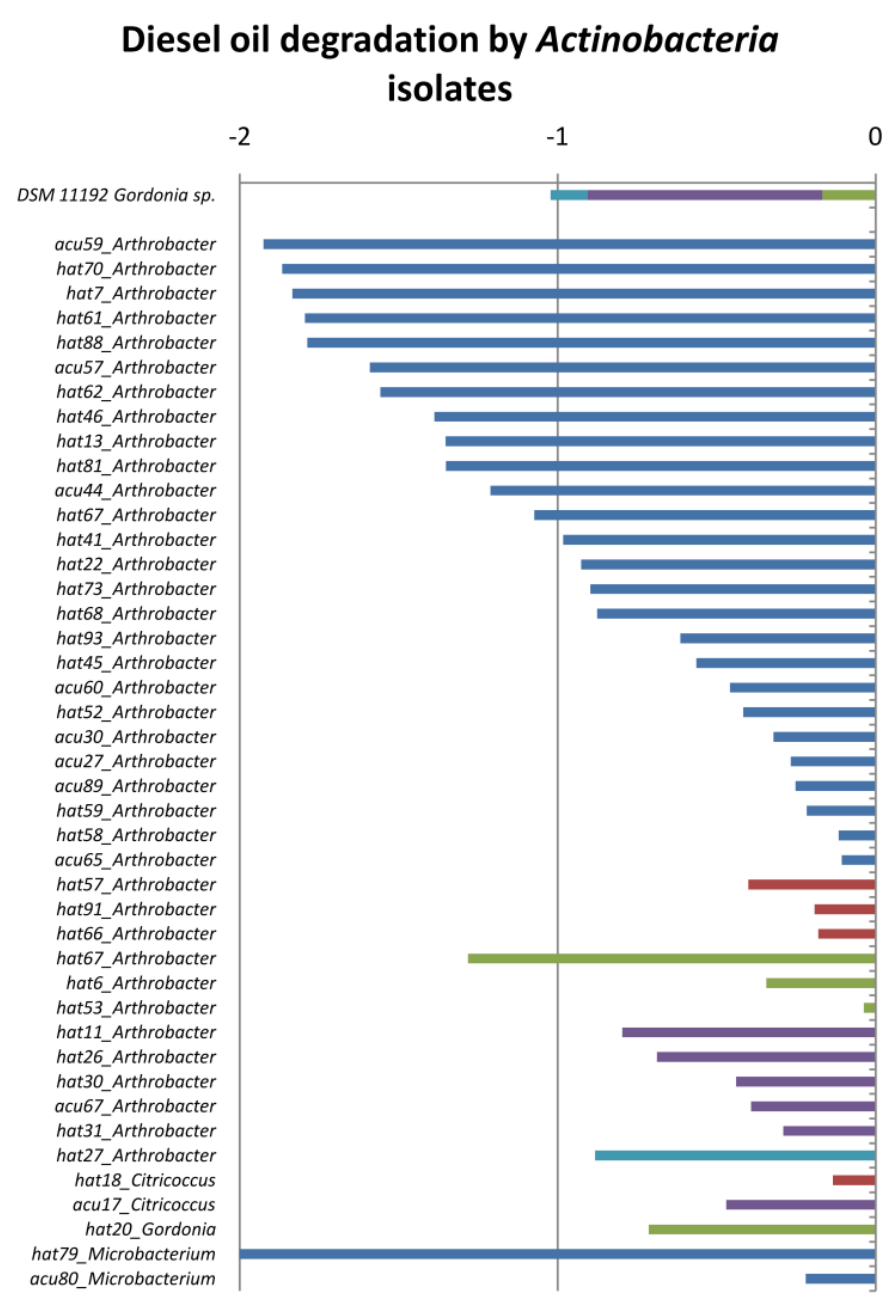

$-3$

DSM 11192 Gordonia sp.

bal34_Achromobacter cal19_Azomonas cal46_Azorhizophilus hat 32 P Pseudomonas hat82_Pseudomonas hat98 Pseudomonas acugs Pseudomonas acu35_Pseudomonas hat92 Pseudomonas hat87 Pseudomonas hat72_Pseudomonas bb12_Pseudomonas bal10 Pseudomonas hat 44 Pseudomonas cal56_Pseudomonas hat35_Pseudomonas cal20_Pseudomonas hat84_Pseudomonas hat60_Pseudomonas acu100_Pseudomonas hat63_Pseudomonas hat36_Pseudomonas hat86-Pseudomanas hat86 Pseudomonas hat7_Pseudomonas cu72.Pseudomonas hat56 Pseudomanas bb23 Pseudomonas cal16 Pseudomonas cal15 Pseudomonas acu99 Pseudomonas hat77_Pseudomonas acu86_Pseudomonas bb47_Pseudomonas cal14_Pseudomonas cal47-Pseudomonas bb16 Pseudomonas hat38 Pseudomonas bal94 Pseudomonas bb37_Pseudomonas bb32_Pseudomonas cal6_Pseudomonas cal39_Pseudomonas acu1_Pseudomonas hat37_Pseudomonas acu87_Pseudomonas cal4_Pseudomonas hat 33 P P seudomonas at100_Pseudomonas hat34_Pseudomonas hat85 Pseudomonas acu23 Pseudomonas hat64_Pseudomonas acu70 Pseudomonas acu37_Pseudomonas acu76_Pseudomonas hat95_Pseudomonas hat50_Pseudomonas acu78_Pseudomonas hat 40_Pseudomonas hatg9_Pseudomonas hat23_Pseudomonas hat94_Pseudomonas bb73 Pseudomonas acu61 Pseudomonas acus Pseudomonas hacus acu79Pseudomonas acu15 Pseudomonas acu34_Pseudomonas acugo Pseudomonas acu15 Pseudomonas acu62 Pseudomonas acug Rhizobium acu96_Stenothrophomonas hat49_Stenothrophomonas hat 43_Stenothrophomonas bal32_Stenothrophomonas hat42_Stenothrophomonas hat69_Stenothrophomonas acu68_Stenothrophomonas acu46_Stenothrophomonas acu40_Stenothrophomonas hat42_-stenothrophomonas

$\begin{array}{lll}-2 & -1 & 0\end{array}$

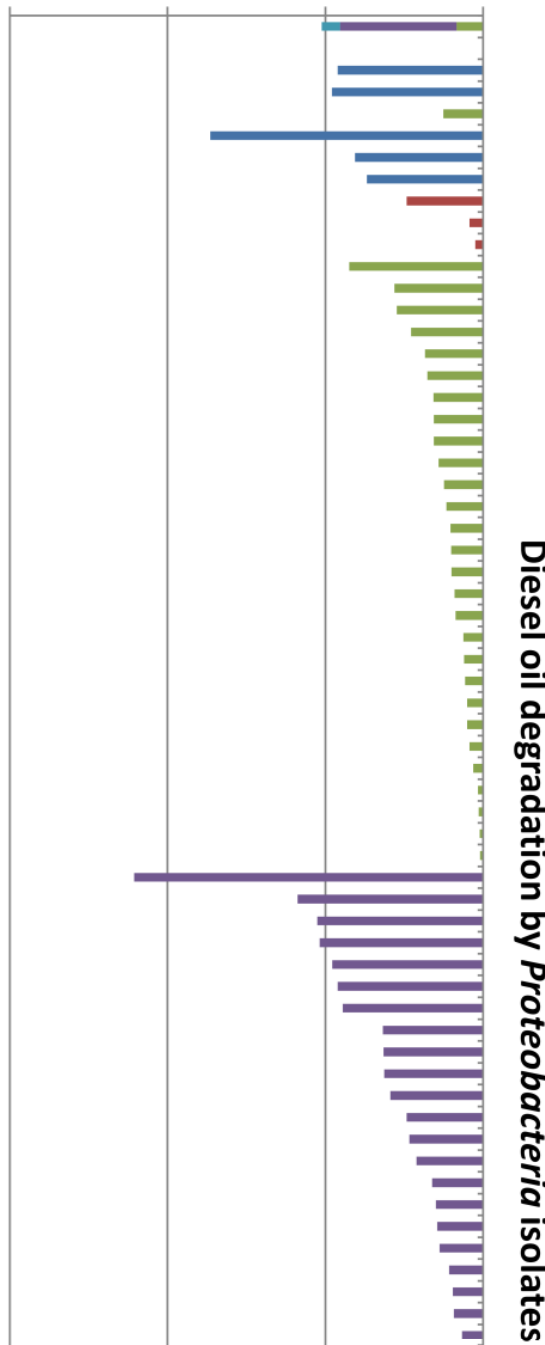




\section{Conclusions}

This work proved isolates that are aromatic hydrocarbon degraders and that can use complex sources of carbon, like phenanthrene and the compost of diesel oil, as carbon and energy sources. Thus, these isolates present great biotechnological potential for the generation of products and process of interest for bioremediation and bioprospection, both for molecules and genes linked to the metabolic pathways of biodegradation. The generated data from this study also provide some information about the role of those microorganisms in nutrient cycling, the process of which directly influences the resilience and fertility associated with ADE.

\section{Acknowledgments}

We thanks Conselho Nacional de Desenvolvimento Científico e Tecnológico (CNPq) and Fundação de Amparo à Pesquisa do Estado de São Paulo (FAPESP) for the financial support; Embrapa Amazônia Ocidental for their technical support and the study area; Instituto Nacional de Pesquisas da Amazônia (INPA) for the technical support; the Aquaculture Division (Escola Superior de Agricultura "Luiz de Queiroz", Universidade de São Paulo campus,ESALQ/USP) for the laboratory support; and Laboratório de Biologia Celular e Molecular (BCM) of Centro de Energia Nuclear na Agricultura of Universidade de São Paulo (CENA/USP) for the laboratory support.

\section{Author Contributions}

Siu Mui Tsai was the project planner and higher supervisor. Mariana Gomes Germano was the sub-supervisor and author who performed part of the collection and analysis of the data. Finally, Fernanda Mancini Nakamura performed part of the collection, as well as the analysis of the data and organized the article, and so, is the contact for this paper.

\section{Conflicts of Interest}

The authors declare no conflict of interest.

\section{References}

1. Glaser, B.; Haumaier, L.; Guggenberger, G.; Zech, W. The "Terra Preta" phenomenon: A model for sustainable agriculture in the humid tropics. Naturwissenschaften 2001, 88, 37-41.

2. Lehmann, J.; Joseph, S. Biochar for Environmental Management; SciTech Earthscan: London, UK, 2009; pp. 1-3.

3. Brady, N.C.; Weil, R.R. An Introduction to the Nature and Properties of Soils, 14th ed.; Prentice Hall: Upper Saddle River, NJ, USA, 2008; p. 881.

4. Steiner, C.; Das, K.C.; Garcia, M.; Forster, B.; Zech, W. Charcoal and smoke extract stimulate the soil microbial community in a highly weathered xanthic Ferralsol. Pedobiologia 2008, 51, 359-366.

5. Habe, H.; Omori, T. Genetic of polycyclic aromatic hydrocarbon metabolism in diverse aerobic bacteria. Biosci. Biotech. Biochem. 2003, 67, 225-243. 
6. Volkering, F.; Breure, A.M.; Sterkenburg, A.; van Andel, J.G. Microbial degradation of polycyclic aromatic hydrocarbons: Effect of substrate availability on bacterial growth kinetics. Appl. Microbiol. Biotechnol. 1992, 36, 548-552.

7. Barkay, T.; Pritchard, H. Adaptation of aquatic microbial communities to pollutant stress. Microbiol. Sci. 1988, 5, 165-169.

8. Spain, J.C.; van Veld, P.A. Adaptation of natural microbial communities to degradation of xenobiotic compounds: Effects of concentration, exposure time, inoculum, and chemical structure. Appl. Environ. Microbiol. 1983, 54, 428-435.

9. Peng, R.; Xiong, A.; Xue, Y.; Fu, X.; Gao, F.; Zhao, W.; Tian, Y.; Ya, Q. Microbial biodegradation of polyaromatic hydrocarbons. FEMS Microbiol. Rev. 2008, 32, 927-955.

10. Sayler, G.S.; Shields, M.S.; Tedford, E.T.; Breen, A.; Hooper, S.W.; Sirotkin, K. M; Davis, J.W. Application of DNA-DNA colony hybridization to the detection of catabolic genotypes in environmental samples. Appl. Environ. Microbiol. 1985, 49, 1295-1303.

11. Park, J.; Crowley, D.E. Dynamic changes in nahAc gene copy numbers during degradation of naphthalene in PAH-contaminated soils. Appl. Microbiol. Biotechnol. 2006, 72, 1322-1329.

12. Lynch, J.M.; Hobbie, J.E. Micro-Organisms in Action: Concepts and Applications in Microbial Ecology; Blackwell Science Inc., Osney Mead: Oxford, UK, 1988; p. 363.

13. Mishra, V.; Lal, R.; Srinivasan. Enzymes and operons mediating xenobiotic degradation in bacteria. Crit. Rev. Microbiol. 2001, 27, 133-166.

14. Navarrete, A.A.; Cannavan, F.S.; Taketani, R.G.; Tsai, S.M. A molecular survey of the diversity of microbial communities in different Amazonian agricultural model systems. Diversity 2010, 2 , 787-809.

15. Germano, M.G.; Cannavan, F.S.; Mendes, L.W.; Lima, A.B.; Teixeira, W.G.; Pellizari, V.H.; Tsai, S.M. Functional diversity of bacterial genes associated with aromatic hydrocarbon degradation in anthropogenic dark earth of Amazonia. Pesqui. Agropec. Bras. 2012, 47, 654-664.

16. Atlas, R.M. Bioremediation of petroleum pollutants. Int. Biodeterior. Biodegrad. 1995, 35, 317-327.

17. Denevan, W. Comments on prehistoric agriculture in Amazônia. Cult. Agric. 1998, 20, 54-59.

18. Furukawa, K. Modification of PCBs by bacteria and others microorganisms. In PCBs and the Environment; Waid, J.S., Ed.; CRC Press: Boca Raton, FL, USA, 1986; p. 84.

19. Doyle, J.J. DNA Protocols for Plants. Mol. Tech. Taxon. NATO ASI Ser. 1991, 57, 283-293.

20. Weisburg, W.G.; Barns, S.M.; Pelletier, D.A.; Lane, D.J. 16S ribosomal DNA amplification for phylogenetic study. J. Bacteriol. 1991, 173, 697-703.

21. Kent, A.D.; Triplett, E.W. Microbial communities and their interactions in soil and rhizosphere ecosystems. Ann. Rev. Microbiol. 2002, 56, 211-236.

22. Ewing, B.; Green, P. Based-calling of automated sequencer traces using Phred. II. Error probabilities. Genome Res. 1998, 8, 186-194.

23. Ewing, B.; Hijjier, L.; Wendl, M.C.; Green, P. Based-calling of automated sequencer traces using Phred. I. Accuracy assessment. Genome Res. 1998, 8, 175-185.

24. Gordon, D.; Abajian, C.; Green, P. Consed: A geographic tool for sequence finishing. Genome Res. 1998, 8, 195-202. 
25. Wang, Q.; Garrity, G.M.; Tiedje, J.M.; Cole, J.R. Naïve bayesian classifier for rapid assignment of rRNA sequences into the new bacterial taxonomy. Appl. Environ. Microbiol. 2007, 73, 5261-5267.

26. Kim, O.S.; Cho, Y.J.; Lee, K.; Yoon, S.H.; Kim, M.; Na, H.; Park, S.C.; Jeon, Y.S.; Lee, J.H.; $\mathrm{Yi}$, H.; et al. Introducing EzTaxon: A prokaryotic $16 S$ rRNA Gene sequence database with phylotypes that represent uncultured species. Int. J. Syst. Evol. Microbiol. 2012, 62, 716-721.

27. Lelliott, R.A.; Stead, D.E. Chapter 5: Host tests methods. In Methods for the Diagnosis of Bacterial Diseases of Plants, 2nd ed.; British Society for Plant Pathology, Blackwell Scientific Publications: Oxford/London, UK, 1987; pp. 167-168.

28. Hanson, K.G.; Desai, J.D.; Desai, A.J. A rapid and simple screening technique for potential crude oil degrading microorganisms. Biotechnol. Tech. 1993, 7, 745-748.

29. Ma, Y.; Wang, L.; Shao, Z. Pseudomonas, the dominant polycyclic aromatic hydrocarbon-degrading bacteria isolated from Antarctic soils and the role of large plasmids in horizontal gene transfer. Environ. Microbiol. 2006, 8, 455-465.

30. Leahy, J.F.; Colwell, R.R. Microbial degradation of hydrocarbons in the environment. Microb. Rev. 1990, 54, 305-315.

31. Pieper, D.H. Aerobic degradation of polychlorinated biphenyls. Appl. Microbiol. Biotechnol. 2005, 67, 170-191.

32. Guzik, U.; Hupert-Kocurek, K.; Sałek, K.; Wojcieszyn'Ska, D. Influence of metal ions on bioremediation activity of protocatechuate 3,4-dioxygenase from Stenotrophomonas maltophilia KB2. World J. Microbiol. Biotechnol. 2013, 29, 267-273.

33. Tuan, N.N.; Hsieh, H.; Lin, Y.; Huang, S. Analysis of bacterial degradation pathways for longchain alkylphenols involving phenol hydroxylase, alkylphenolmonooxygenase and catechol dioxygenase genes. Bior. Technol. 2011, 102, 4232-4240.

34. Reinhold, B.; Hurek, T.; Fendrik, I. Cross-reaction of predominant nitrogen-fixing bacteria with enveloped, round bodies in the root interior of kallar grass. Appl. Environ. Microbiol. 1987, 53, 889-891.

35. Juhasz, A.L.; Naidu, R. Bioremediation of high molecular weight polycyclic aromatic hydrocarbons: A review of the microbial degradation of benzo[a]pyrene. Int. Biodeterior. Biodegrad. 2000, 45, 57-88.

36. Pathak, A.; Green, S.J.; Ogram, A.; Chauhan, A. Draft genome sequence of Rhodococcusopacus strain M213 shows a diverse catabolic potential. Genome. Announc. 2013, doi:10.1128/genomeA.00144-12.

37. Mutnuri, S.; Vasudevan, N.; Kaestner, M. Degradation of anthracene and pyrene supplied by microcrystals and non-aqueous-phase liquids. Appl. Microbiol. Biotech. 2005, 67, 569-576.

38. Kanashiro, C.H.; Arredondo, D.L.L.; Morales, P.C.; Alcaraz, L.; Olmedo, G.; Gómez, F.B.; Estrella, L.H. First Draft Genome Sequence of a Strain from the Genus Citricoccus. J. Bact. 2011, 193, 6092-6093.

39. Van Aken, B.; Yoon, J.M.; Schnoor, J.L. Biodegradation of nitro-substituted explosives 2,4,6-trinitrotoluene, hexahydro-1,3,5-trinitro-1,3,5-triazine, and octahydro-1,3,5,7-tetranitro-1,3,5tetrazocine by a phytosymbiotic Methylobacterium sp. associated with poplar tissues (Populus deltoids x nigra DN34). Appl. Environ. Microbiol. 2004, 70, 508-517. 
40. Daane, L.L.; Harjono, I.; Zylstra, G.J.; Haggblom, M.M. Isolation and characterization of polycyclic aromatic hydrocarbons-degrading bacteria associated with the rhizosphere of salt marsh plants. Appl. Environ. Microbiol. 2011, 67, 2683-2691.

41. Agency for Toxic Substances and Disease Registry (ATSDR). Toxicological Profile for Fuel Oils; U.S. Department of Health and Human Services, Public Health Service: Atlanta, GA, USA, 1995.

(C) 2014 by the authors; licensee MDPI, Basel, Switzerland. This article is an open access article distributed under the terms and conditions of the Creative Commons Attribution license (http://creativecommons.org/licenses/by/3.0/). 